of nitrogen up to 1.8 per cent. may be made to combine with the metal. The most favorable temperature is $700^{\circ}$.

The most favorable temperature for the formation of nitride of iron is $450-475^{\circ}$. On account of the high dissociation pressure of the nitride at this temperature the nitride formed must always contain less than the theoretical percentage of nitrogen. Preparations with ro per cent. of nitrogen were scarcely appreciably attacked by neutral potassium copper chloride and although slowly attacked by acid solutions did not change their percentage composition. They can not therefore be mechanical mixtures of free iron and nitride and are preferably to be regarded as solid solutions, as is the case with nitride of chromium and chromium. From analogy with other bivalent elements iron should form the nitride $\mathrm{Fe}_{3} \mathrm{~N}_{2}$ and the preparations may be represented by the formula $\mathrm{Fe}_{3} \mathrm{~N}_{2}+x \mathrm{Fe}$.

UXIVERSTTY OF MICHIGAN,

ANX ARBOR, July, 1906 .

[CONTRIBUTION FROM THE JOHN HARRISON LABORATORY OF CHEMISTRY, NO. IOO.]

\title{
THE ELECTROLYTIC PRECIPITATION OF GOLD WITH THE USE OF A ROTATING ANODE.'
}

BY JAMES RENWICK WITHROW.

Received Ju1y 30 , I906.

THE electrolytes used in this investigation were solutions of auric chloride in the presence of (I) potassium cyanide and (2) sodium sulphide. The rate of precipitation of the metal was especially studied. The results show that pure potassium cyanide is evidently a better electrolyte than sodium sulphide for this particular purpose.

The apparatus used in the experiments was similar to that described by Ingham. ${ }^{2}$ The first series of experiments with the cyanide electrolyte was made under conditions prescribed by Exner. ${ }^{3}$ They were as follows:

1 From the author's thesis for the Ph.D. degree.

2 This Journal, 26, I 269.

3 Ibid. 26, 1256. 


\begin{tabular}{|c|c|c|c|c|c|c|c|}
\hline No. & $\begin{array}{c}\text { Gold taken. } \\
\text { Gram. }\end{array}$ & $\begin{array}{c}\text { KCN. } \\
\text { Grams. }\end{array}$ & $\begin{array}{l}\text { Dilution. } \\
\text { cc. }\end{array}$ & $\begin{array}{l}\text { Curreat. } \\
\text { Amperes. }\end{array}$ & Volts. & $\begin{array}{l}\text { Time. } \\
\text { Minutes. }\end{array}$ & $\begin{array}{l}\text { Gold found. } \\
\text { Grans. }\end{array}$ \\
\hline $1 \ldots$ & . 0.1377 & 1.5 & 103 & 5 & $13-10.5$ & 10 & 0.1377 \\
\hline $2 \ldots$ & . 0.1377 & I. 5 & 78 & 5 & II -10.5 & 10 & 0.1372 \\
\hline $3 \ldots$ & 0.1377 & 1.5 & 78 & 5 & $10.5-8.5$ & Io & 0.1372 \\
\hline $4 \ldots$ & .0 .1377 & I. 5 & 78 & 5 & $10.5-10$ & 6 & 0.1378 \\
\hline $5 \ldots$ & . 0.1377 & 1.5 & 78 & 5 & $10.5-9$ & 4 & $0.137^{\circ}$ \\
\hline
\end{tabular}

The deposits were washed without interrupting the current. Usually a liter of water was required for the purpose. They were of a beautiful gold-yellow color, and consisted of microscopic, very adherent needles. It was not found necessary to let them stand in a desiccator before weighing, but after the ether had been volatilized by the heat of the hand, the dish was rubbed with a chamois skin and placed on the balance pan where it came to a constant weight in a few minutes.

The results confirm Exner's observations in every particular. Even less time than mentioned by him is sufficient for complete precipitation.

To ascertain the minimum time in which it was possible to make a complete precipitation, the following trials were conducted:

\begin{tabular}{|c|c|c|c|c|c|c|}
\hline $\begin{array}{l}\text { Gold taken. } \\
\text { Gram. }\end{array}$ & $\begin{array}{c}\text { KCN. } \\
\text { Grams. }\end{array}$ & $\begin{array}{l}\text { Dilution. } \\
\text { cc. }\end{array}$ & $\begin{array}{l}\text { Current. } \\
\text { Amperes. }\end{array}$ & Volts. & $\begin{array}{l}\text { Time. } \\
\text { Minutes. }\end{array}$ & $\begin{array}{l}\text { Gold found. } \\
\text { Gram. }\end{array}$ \\
\hline I. . 0.2754 & 2.5 & 80 & 5 & $8-7$ & 10 & 0.2747 \\
\hline $2 \ldots 0.2754$ & 2.5 & 80 & 5 & & 5 & 0.2706 \\
\hline $3 \ldots 0.2754$ & 2.5 & 80 & 5 & $7.6-6.7$ & 6 & 0.2720 \\
\hline $4 \ldots \ldots .2754$ & 2.5 & 80 & 5 & $7.5-6.7$ & 8 & 0.2754 \\
\hline $5 \ldots .0 .2754$ & 2.5 & 80 & 7 & $9.5-9$ & 7 & $0.274^{8}$ \\
\hline $6 \ldots 0.2754$ & 2.5 & 80 & 10 & $14 \cdot 5^{-13}$ & 2 & 0.2667 \\
\hline $7 \ldots 0.2754$ & 2.5 & 80 & IO & $17-13$ & 3 & 0.2724 \\
\hline $8 \ldots .0 .2754$ & 5.0 & 85 & Io & I7 -IO & 3 & 0.2319 \\
\hline $9 \ldots \quad 0.2754$ & 2.5 & 80 & Io & $16-12$ & 3 & 0.2704 \\
\hline $10 . \ldots \quad 0.2754$ & 2.5 & 80 & I 2 & 15 & 2 & 0.2476 \\
\hline II . . 0.2754 & 2.5 & 80 & 10 & 15 & 4 & 0.2750 \\
\hline $12 \ldots 0.2754$ & 2.5 & 80 & I 2 & $19-12$ & 3 & $0.262 \mathrm{I}$ \\
\hline $13 \ldots, 0.2754$ & 2.0 & 55 & I $2-10$ & $2 I-18$ & 3 & 0.2742 \\
\hline
\end{tabular}

An inspection of this table reveals the fact, as seen in Expts. I to 4 , that eight minutes are necessary to precipitate all of the gold. On increasing the current to seven amperes the gold was completely deposited in seven minutes. In the eleventh trial fifteen amperes were used and only four minutes were consumed in the deposition. In the trials from the sixth to the eleventh foaming of the electrolyte led to loss.

To learn the result of a still greater concentration of the electrolyte, the following experiments were carried out: 


\begin{tabular}{|c|c|c|c|c|c|c|c|c|}
\hline $\begin{array}{c}\text { Gold taken. } \\
\text { No. Gram. }\end{array}$ & $\begin{array}{l}\mathrm{KCN} .1 \\
\text { Grams. }\end{array}$ & $\begin{array}{l}\text { Dilution. } \\
\text { sc. }\end{array}$ & $\begin{array}{l}\text { Current. } \\
\text { Amperes. }\end{array}$ & & olts. & $\begin{array}{l}\text { Speed per } \\
\text { minute. }\end{array}$ & $\begin{array}{l}\text { Time. } \\
\text { Minutes. }\end{array}$ & $\begin{array}{l}\text { Gold found. } \\
\text { Gram. }\end{array}$ \\
\hline I . . . $0.262 \mathrm{I}$ & I. 5 & I 50 & $0.27-0.2$ & 3.9 & & none & 130 & 0.2621 \\
\hline $2 \ldots 0.262 \mathrm{I}$ & 2.5 & 80 & -5 & II & -7.5 & 800 & I0 & $0.262 \mathrm{I}$ \\
\hline $3 \ldots 0.262 \mathrm{I}$ & 2.5 & 55 & I2 & 18 & -3.5 & 800 & 3 & 0.2588 \\
\hline $4 \ldots 0.262 \mathrm{I}$ & 2.5 & 30 & I 2 & II & -6.5 & 800 & 3 & $0.26 \mathrm{II}$ \\
\hline $5 \ldots 0.262 \mathrm{I}$ & 2.5 & 30 & 12 & 13 & & 800 & 3 & 0.2618 \\
\hline $6 \ldots .0 .262 \mathrm{I}$ & 2.5 & 30 & I 2 & I 1.5 & -6 & 800 & 3 & 0.2602 \\
\hline $7 \ldots 0.262 \mathrm{I}$ & 2.5 & 30 & I 2 & I I & -9.5 & 800 & 3 & 0.2608 \\
\hline $8 \ldots 0.262 \mathrm{I}$ & 2.5 & 55 & I 2 & 38 & -10 & 800 & 4 & 0.2620 \\
\hline $9 \ldots 0.262 \mathrm{I}$ & 2.5 & 55 & Io & 16 & -11 & 800 & 4 & 0.2604 \\
\hline 10... 0.2621 & 5 & 60 & I 2 & 17 & -10 & 800 & 3.5 & 0.2585 \\
\hline I I $\ldots 0.262$ I & 2.5 & 55 & I 2 & $2 I$ & & 800 & $\mathbf{I}$ & 0.0959 \\
\hline I $2 \ldots 0.262 x$ & 2.5 & 55 & 12 & 25 & & 800 & 2 & 0.2406 \\
\hline I $3 \ldots, 0.262$ I & 2.5 & 55 & $\mathrm{I} 2$ & I 6.5 & -10.5 & 800 & 4 & 0.2619 \\
\hline $\mathrm{I} 4 \ldots, 0.262 \mathrm{I}$ & 2.5 & 55 & I 2 & 14 & -9 & 800 & 4 & 0.2614 \\
\hline $15 \ldots 0.262 \mathrm{I}$ & 2.5 & 55 & I2 & 14 & -12 & . & 4 & 0.2600 \\
\hline $16 \ldots 0.2621$ & 2.5 & 55 & 12 & II & -10 & 380 & 4 & 0.2494 \\
\hline I $7 \ldots 0.2621$ & 2.5 & 55 & I2 & 15 & -10 & 600 & 4 & $0.257 \mathrm{I}$ \\
\hline I8 . . .0.262I & 2.5 & 55 & I 2 & 19 & -13 & 800 & 4 & 0.2615 \\
\hline I9 . . .0.2621 & 2.5 & 55 & I 2 & 17 & -12 & 800 & 1 & 0.1265 \\
\hline $20 \ldots .0 .062 \mathrm{I}$ & 2.5 & 55 & I 2 & 18 & $-I I$ & 765 & 4 & 0.2612 \\
\hline $21 \ldots \circ 262 \mathrm{I}$ & 2.5 & 55 & I2 & I9 & -12 & 900 & 4 & $0.26 \mathrm{r} 2$ \\
\hline $22 \ldots, 0.2621$ & 2.5 & 55 & I 3 & $2 \mathrm{I}$ & -12 & 790 & 4 & 0.2606 \\
\hline $23 \ldots 0.262 \mathrm{I}$ & 2.5 & 55 & I5 & 12.5 & -10 & 450 & 4 & 0.2546 \\
\hline $24 \ldots 0.262 \mathrm{I}$ & 2.5 & 80 & I5 & $\mathrm{I} 4$ & -13 & 450 & 4 & 0.2412 \\
\hline $25 \ldots 0.262 \mathrm{I}$ & 2.5 & 75 & I5 & 16 & -10 & 740 & 4 & 0.2610 \\
\hline $26 \ldots 0.262 \mathrm{I}$ & 2.5 & 80 & I5 & 16 & -10 & 850 & 4 & $0.261 \mathrm{r}$ \\
\hline
\end{tabular}

The conclusion drawn from this series was that a current of not more than ten amperes should be used, the other conditions remaining the same. Higher currents produced boiling of the electrolyte. There was also variation in the speed of the rotator, and these two factors militated against getting constant results in the minimum space of time. In the succeeding determinations, therefore, only the conditions found most satisfactory in the last series were employed:

\begin{tabular}{|c|c|c|c|c|c|c|c|}
\hline $\begin{array}{c}\text { Gold taken. } \\
\text { No. Gram. }\end{array}$ & $\begin{array}{l}\text { KCN. } \\
\text { Grams. }\end{array}$ & $\begin{array}{l}\text { Dilution. } \\
\text { cc. }\end{array}$ & $\begin{array}{l}\text { Current. } \\
\text { Amperes. }\end{array}$ & Volts. & $\begin{array}{c}\text { Speed } \\
\text { per } \\
\text { minute. }\end{array}$ & $\begin{array}{l}\text { Time. } \\
\text { Minutes. }\end{array}$ & $\begin{array}{l}\text { Gold } \\
\text { found } \\
\text { Gram. }\end{array}$ \\
\hline I . . .0.261 I & 2.5 & 80 & 7.0 & IO & 800 & 12 & $0.26 \mathrm{II}$ \\
\hline $2 \ldots 0.26 \mathrm{II}$ & 2.5 & 80 & $10.2-10$ & I I.4-10 & 800 & 5 & $0.26 \mathrm{r} 2$ \\
\hline $3 \ldots 0.26 \mathrm{r} \mathrm{I}$ & 2.5 & 80 & Io & $14.7-9.6$ & 860 & 5 & 0.2598 \\
\hline $4 \ldots .0 .261$ I & 2.5 & 80 & IO & I0 -8 & 620 & 5 & 0.2527 \\
\hline $5 \ldots 0.26 \mathrm{II}$ & 2.5 & 80 & 10 & $I_{4}-9.6$ & 820 & 7 & 0.2614 \\
\hline $6 \ldots .0 .26 \mathrm{II}$ & 2.5 & 80 & $10.2-10$ & $10.8-9$ & . & 7 & 0.2609 \\
\hline $7 \ldots 0.26 \mathrm{II}$ & 2.5 & 80 & Io & I4 - IO & 820 & 10 & 0.2612 \\
\hline $8 \ldots .0 .26 \mathrm{II}$ & 2.5 & 80 & IO & $14-9$ & 770 & 10 & $0.26 \mathrm{I} 6$ \\
\hline
\end{tabular}




\begin{tabular}{|c|c|c|c|c|c|c|c|}
\hline $\begin{array}{l}\text { Gold taken. } \\
\text { No. Gram. }\end{array}$ & $\begin{array}{l}\mathrm{KCN} . \\
\text { Grams. }\end{array}$ & $\begin{array}{c}\text { Dilution. } \\
\text { cc. }\end{array}$ & $\begin{array}{l}\text { Current. } \\
\text { Amperes. }\end{array}$ & Volts. & $\begin{array}{c}\text { Speed } \\
\text { per } \\
\text { minute. }\end{array}$ & $\begin{array}{l}\text { Time. } \\
\text { Minutes. }\end{array}$ & $\begin{array}{l}\text { Gold } \\
\text { found. } \\
\text { Gram. }\end{array}$ \\
\hline $9 \ldots 0.26 \mathrm{II}$ & 2.5 & 80 & 10 & $13-9.5$ & 800 & 7 & 0.2615 \\
\hline $10 \ldots . .0 .26 \mathrm{II}$ & 2.5 & 80 & 10 -10.5 & $13.5-10$ & 830 & 7 & $0.26 \mathrm{II}$ \\
\hline II $\ldots 0.26 \mathrm{II}$ & 2.5 & 80 & 10 & $15-12$ & 795 & $\mathbf{I}$ & 0.1054 \\
\hline $12 \ldots 0.26 \mathrm{II}$ & 2.5 & 80 & 10 & I $3.5-9.5$ & 850 & 2 & 0.2049 \\
\hline $13 \ldots 0.2611$ & 2.5 & 80 & IO & $13.5-9.5$ & 815 & 3 & 0.2420 \\
\hline $14 \ldots 0.26 \mathrm{II}$ & 2.5 & 80 & 10 & I 5.5-10 & 820 & 4 & $0.25^{82}$ \\
\hline $15 \ldots 0.2611$ & 2.5 & 80 & 10 & $14.7-9.6$ & 860 & 5 & 0.2598 \\
\hline $16 \ldots 0.261 x$ & 2.5 & 80 & 10 & $14-9$ & 8 Io & 6 & 0.2613 \\
\hline $17 \ldots 0.2611$ & 2.5 & 80 & Io & $14-10.1$ & 776 & 7 & 0.2614 \\
\hline $18 \ldots 0.2611$ & 2.5 & 80 & 10 & $14-10$ & 830 & 7 & 0.2613 \\
\hline
\end{tabular}

Beginning with Expt. 5, the current of ten amperes was regularly employed with an accompanying speed in the rotator of 800 revolutions per minute. The electrolyte was not previously heated from without. The points in the curve marked " $\mathrm{KCN}$ No. I" in the figure were obtained from the eleventh experiment. Upon substituting a more concentrated gold solution-one containing 0.5222 gram-the final series was obtained:

\begin{tabular}{|c|c|c|c|c|c|c|c|}
\hline $\begin{array}{l}\text { Gold taken } \\
\text { No. Gram. }\end{array}$ & $\begin{array}{l}\mathrm{KCN} . \\
\text { Gtams. }\end{array}$ & ce. & $\begin{array}{l}\text { Current. } \\
\text { Amperes. }\end{array}$ & Volts. & $\begin{array}{l}\text { Speed per } \\
\text { minute. }\end{array}$ & $\begin{array}{l}\text { Time. } \\
\text { minute. }\end{array}$ & $\begin{array}{l}\text { Gold found. } \\
\text { Gram. }\end{array}$ \\
\hline I . . 0.5222 & 5 & 60 & 10 & $10-8$ & 800 & 10 & 0.5216 \\
\hline $2 \ldots 0.5222$ & 5 & 60 & $10-10.2$ & 10 -7.3 & 800 & 12 & 0.5226 \\
\hline $3 \ldots 0.5222$ & 2.5 & 55 & I0 -10.8 & I $4.5-9.6$ & 800 & 10 & 0.5222 \\
\hline $4 \ldots 0.5222$ & 2.5 & 55 & 10 -10.3 & I $4-9.4$ & 810 & 12 & 0.5234 \\
\hline $5 \ldots 0.5465$ & 3.5 & 60 & $10-10.5$ & $8.3-7$ & 790 & 12 & 0.5461 \\
\hline $6 \ldots 0.5465$ & 5 & 60 & $10-10.2$ & $9.3-8.3$ & 790 & I & 0.1891 \\
\hline $7 \ldots 0.5465$ & 5 & 60 & $10.2-10.5$ & $8.3-7$ & 800 & 3 & 0.4341 \\
\hline $8 \ldots . .5465$ & 5 & 60 & $10-10.3$ & $9.6-7.1$ & 825 & 5 & 0.5286 \\
\hline $9 \ldots .5465$ & 5 & 60 & ro & $8.6-6.7$ & 780 & 7 & 0.5437 \\
\hline 10. . . . 0.5465 & 5 & 60 & $10.3-10$ & $8.3-6.3$ & 790 & I I & 0.5468 \\
\hline I I . . . 0.5465 & 5 & 60 & IO & $7.8-6.8$ & 790 & 12 & 0.5467 \\
\hline
\end{tabular}

From the first and second determinations it was seen that the gold was completely precipitated in ten to twelve minutes. No. 3 was then tried to see if less potassium cyanide could be used as it might exert a retarding influence on the rate of precipitation. The result was satisfactory but there was quite a perceptible deposit on the anode, resembling yellow pollen. This was probably an oxide of gold. It dissolved instantly in concentrated hydrochloric acid.

It may be mentioned here that this anodic stain or deposit was also noticed in several of the determinations, made with a station- 
ary anode as checks on the work with the rotator. Especially was this so when the time of precipitation exceeded two hours. It was observed even with deposits weighing only 0.25 gram, with which amount it was never observed when the rotator was used, nor was it mentioned by Miller, ${ }^{1}$ who, however, never precipitated more than 0.1697 gram of metal.

The anodic deposit having been eliminated by the use of an excess of potassium cyanide, the determinations from No. 6 on, furnished the points on the curve marked "KCN No. 2." Those deposits in which 0.5 gram of gold was completely precipitated were generally not so bright and were of a darker color than the 0.25 gram deposits.

Upon substituting sodium sulphide for potassium cyanide and electrolyzing the gold solution in its presence, very satisfactory results were obtained. The sodium sulphide was of the specific gravity I.165. At the beginning, the gold solution was pipetted into a platinum dish and the sodium sulphide was added to it. This proved far from satisfactory because particles of gold sulphide adhered to the sides of the dish and it proved rather difficult to bring them completely into solution, so the expedient was adopted of first introducing the sodium sulphide solution into the dish, starting the rotator and then allowing the solution of gold chloride to run in from a pipette. No precipitate at all was formed and the liquid assumed a deep reddish brown or ferric sulphocyanide color, which, on heating, changed to a clear olive-green. The solution became cloudy during the decomposition from the separation of free sulphur. The anode was coated with a loose layer of sulphur. Rinsing with water sufficed to free the deposits from sulphur, after they were washed with hot water and dried in the ustal way. The metallic deposits varied somewhat in color, that in Expt. 9 being beautifully burnished and rich yellow in hue. The curve marked $\mathrm{Na}_{2} \mathrm{~S}$ in the figure, was constructed from determinations made with 0.25 gram of metal in solution. It is worthy of note that the 0.25 gram curves in the two electrolytes-potassium cyanide and soldium sulphideare almost identical. Probably they would have been exactly so if the same amounts had been used in each case.

1 This Journal, 26, 1256. 


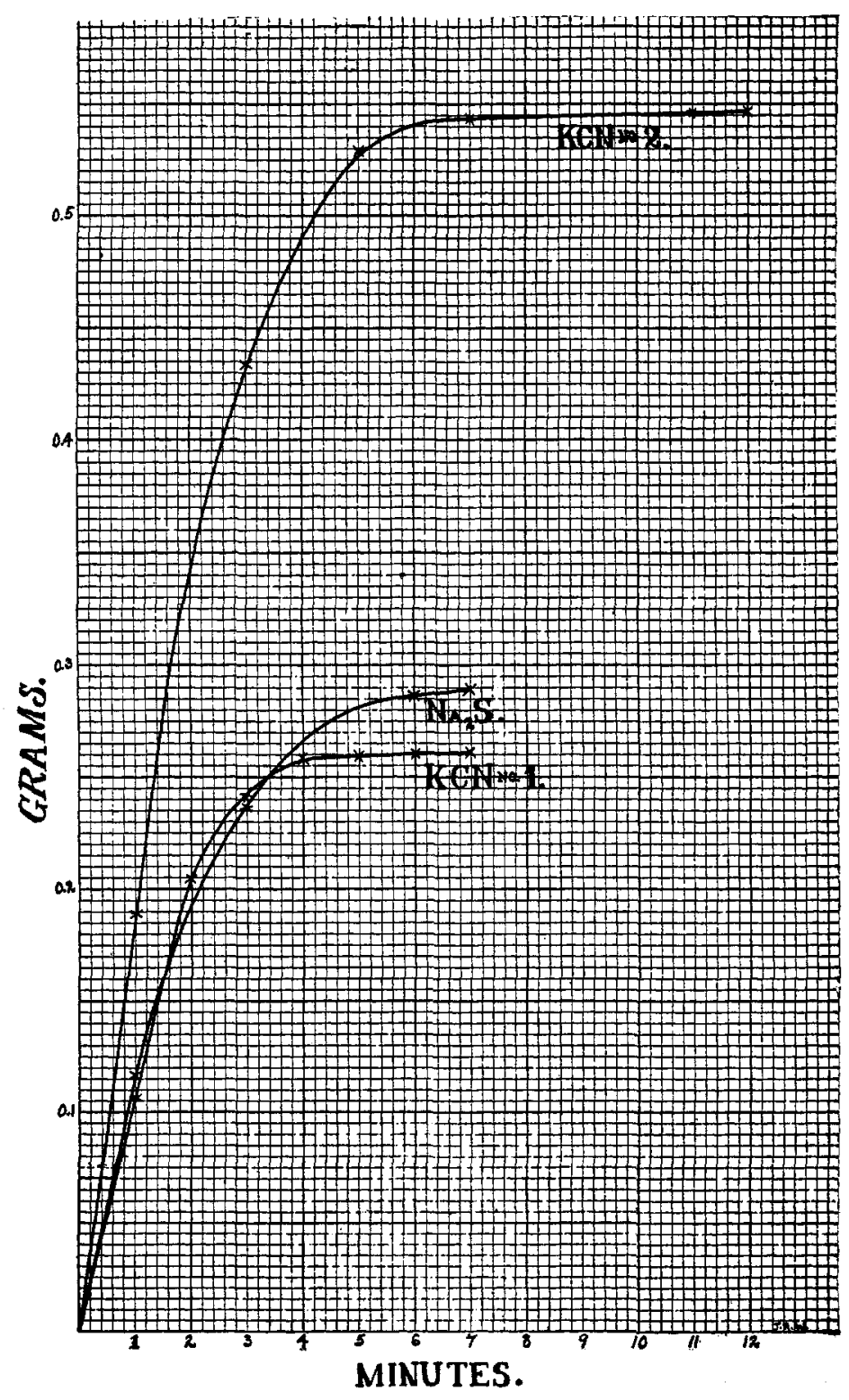




\begin{tabular}{|c|c|c|c|c|c|c|c|}
\hline $\begin{array}{c}\text { Gold taken. } \\
\text { Nram. }\end{array}$ & $\begin{array}{l}\mathrm{Na}_{2} \mathrm{~S} \\
\mathrm{ce}\end{array}$ & $\begin{array}{c}\text { Dintior } \\
\mathrm{cc} \text {. }\end{array}$ & $\begin{array}{l}\text { 11. Current. } \\
\text { Anperes. }\end{array}$ & Volts. & $\begin{array}{l}\text { Speed per } \\
\text { miaute. }\end{array}$ & $\begin{array}{l}\text { Time. } \\
\text { Minutes. }\end{array}$ & $\begin{array}{l}\text { old found } \\
\text { Gram. }\end{array}$ \\
\hline I $\ldots .0 .2878$ & I5 & 60 & $10-8.8$ & $7.6-7.2$ & 810 & 7 & $0.289 \mathrm{I}$ \\
\hline $2 \ldots 0,2878$ & 30 & 60 & $10.1-10.3$ & $6.9-6$ & 840 & 7 & 0.2879 \\
\hline $3 \ldots 0.2878$ & 30 & 60 & $9.8-$ IO. I & 7.8 & 830 & 7 & 0.2897 \\
\hline $4 \ldots .0 .2878$ & I 5 & 60 & 10 -9.8 & II. $6-$ I I.I & 840 & 7 & 0.2898 \\
\hline $5 \ldots 0.2878$ & 20 & 60 & 10 & II.6-9 & 800 & 7 & 0.2905 \\
\hline $6 \ldots, 0,2878$ & 30 & 60 & $10.2-10.5$ & $8.8-7.4$ & 830 & 7 & 0.2883 \\
\hline $7 \ldots 0.2878$ & 20 & 60 & IO. $1-10$ & $9.1-8.2$ & 850 & 7 & 0.2885 \\
\hline $8 \ldots . .0 .2878$ & I 5 & 60 & IO & I $1.5-10$ & 840 & 7 & 0.2887 \\
\hline $9 \ldots 0.2878$ & 30 & 60 & $10.1-10$ & $9.4-8.5$ & 850 & I & 0.1165 \\
\hline 10. . .0.2878 & 30 & 60 & IO & $\begin{array}{ll}8 & -7\end{array}$ & 850 & 6 & 0.2870 \\
\hline $11 \ldots 0.2878$ & 30 & 60 & $10-10.2$ & $9-7.9$ & 850 & 3 & 0.2365 \\
\hline
\end{tabular}

It was also found that as much as 0.5 gram of metal could be completely precipitated in adherent form in a period of time not exceeding twelve minutes.

Another subject that received some attention was the electrolytic analysis of alkali halides. The complete determination of the components of such salts was shown by Smith to be quite possible when ${ }^{1}$ using a mercury cathode and a silver-plated gauze as anode.

In an attempt to get iodine into an adherent deposit a rotator was used, thinking that the deposit might in this way be so compacted as to adhere firmly. The spiral cathode was accordingly rotated from 300 to 500 revolutions per minute, while a silverplated dish was made the anode. The total dilution was about $70 \mathrm{cc}$. The following results were obtained:

\begin{tabular}{|c|c|c|c|c|c|c|c|c|}
\hline \multirow[b]{2}{*}{ No. } & \multirow[b]{2}{*}{$\begin{array}{c}\text { KI taken. } \\
\text { Gram. }\end{array}$} & \multirow[b]{2}{*}{$\begin{array}{l}\text { Current. } \\
\text { Ampere. }\end{array}$} & \multirow[b]{2}{*}{ Volts. } & \multirow[b]{2}{*}{$\begin{array}{l}\text { Time. } \\
\text { Minutes. }\end{array}$} & & \multicolumn{2}{|c|}{ Iodine } \\
\hline & & & & & $\begin{array}{l}\text { found. } \\
\text { Gram. }\end{array}$ & $\begin{array}{c}\text { present. } \\
\text { Gram. }\end{array}$ & $\begin{array}{l}\text { found. } \\
\text { Gram. }\end{array}$ & $\begin{array}{l}\text { present. } \\
\text { Gram. }\end{array}$ \\
\hline I. & .0 .0400 & & $2.5^{-2} .4$ & I 5 & 0.0094 & 0.0094 & 0,0280 & 0.0306 \\
\hline 2. & .0 .0400 & & $2.8-2.7$ & I 6 & 0.0094 & 0.0094 & 0.0307 & 0.0306 \\
\hline & .0 .0400 & $\ldots$ & $3.0-2.8$ & 18 & 0.0095 & 0.0094 & 0.0300 & 0.0306 \\
\hline
\end{tabular}

The cover glasses and the inner sides of the dish were washed down with distilled water shortly before the end of the determination. When the deposition was complete the dish was washed either by the usual siphoning method without interrupting the current or it was immediately withdrawn and the contents poured into a beaker and then rinsed several times with small portions of distilled water and $\mathrm{d}$ ried in an air-bath, as was done with the gauze in the previous work. The former method was the safer

1 This Journal, 52,890 . 
of the two and was the one generally employed. In either case the wash-waters were carefully preserved and titrated for the potassium hydroxide.

Potassium chloride was tried in the same manner and very excellent, adherent deposits were quickly obtained.

\begin{tabular}{|c|c|c|c|c|c|c|c|}
\hline \multirow[b]{2}{*}{$\begin{array}{c}\text { KCl taken. } \\
\text { Gram. }\end{array}$} & \multirow[b]{2}{*}{$\begin{array}{l}\text { Current. } \\
\text { Ampere. }\end{array}$} & \multirow[b]{2}{*}{ Volts. } & \multirow[b]{2}{*}{$\begin{array}{c}\text { Time. } \\
\text { Minutes. }\end{array}$} & & \\
\hline & & & & foun & $\begin{array}{l}\text { presentt. } \\
\text { Grams. }\end{array}$ & $\begin{array}{l}\text { found. } \\
\text { Gram. }\end{array}$ & at. \\
\hline .0 .0400 & $0.055-0.07$ & $9-3.8$ & I 5 & 0.0207 & 0.0209 & 0.0190 & 0.0191 \\
\hline 2...0.0400 & 0.08 & 5 & I5 & 0.0208 & 0.0209 & 0.0206 & 0.0191 \\
\hline.$\infty$ & $0.08-0.08$ & $8-3.4$ & I & 0205 & 09 & 0.0187 & D.0I9I \\
\hline 0.0400 & $0.08-0.09$ & 3.6 & 0 & 0.0205 & 0.0209 & 0.0 & 0.0191 \\
\hline $5 \ldots \ldots$. & $0.08-0.09$ & $4.2-3.8$ & 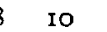 & $0.02 I I$ & 0.0209 & 0.0189 & 0.0191 \\
\hline 0 & $0.08-0.09$ & -4.7 & IO & 0,0198 & 99 & 0.0180 & 0.0191 \\
\hline 0.0400 & $0.08-0.09$ & $6.3-4.7$ & Io & $0.021 \mathrm{I}$ & 0.0209 & 0.0187 & 0.0191 \\
\hline
\end{tabular}

The same conditions were used as in the analysis of potassium iodide with aid of the rotator.

UnIVERsity OF PENASYIVANia.

\section{THE DISSOCIATION OF WATER VAPOR AND CARBON DIOXIDE AT HIGH TEMPERATURES.}

BY IRVING IANGMUIR.

THE dissociation of gases at high temperatures has been the subject of many investigations during the past few years. In particular the states of equilibrium in the following reactions have been studied:

$$
\begin{aligned}
& { }_{2} \mathrm{HI} \stackrel{\mathrm{I}}{\longleftrightarrow}+\mathrm{I}_{2},{ }^{1}
\end{aligned}
$$

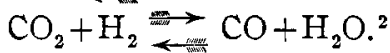

$$
\begin{aligned}
& { }_{2} \mathrm{SO}_{3} \stackrel{2}{\longrightarrow} \mathrm{SO}_{2}+\mathrm{O}_{2}{ }^{3} \\
& { }_{2} \mathrm{NO} \mathrm{N}_{2}+\mathrm{O}_{2}{ }^{4} \\
& { }_{2} \mathrm{CO}_{2} \stackrel{2}{\longleftrightarrow} 2 \mathrm{CO}+\mathrm{O}_{2}{ }^{5} \\
& { }_{2} \mathrm{H}_{2} \mathrm{O} \stackrel{2}{\longrightarrow} \mathrm{H}_{2}+\mathrm{O}_{2}{ }^{5} \\
& { }_{2} \mathrm{NH}_{3} \stackrel{\mathrm{N}=}{\longleftrightarrow} \mathrm{N}_{2}+{ }_{3} \mathrm{H}_{2} \cdot{ }^{6}
\end{aligned}
$$

1 Bodenstein: Z. physik. Chem. 29, 295 ( 1899 ).

${ }^{2}$ Hahn: Ibid. 44, 5 I3 (1903); 48, 735 (I g04).

${ }^{3}$ Knietsch: Ber. 34, 4069 (I90r); Bodenstein: Z. Electrochem. II, 373 (1905).

4 Nernst: Göttinger Nachr. I904, Heft 4.

${ }^{5}$ Nernst and v. Wartenberg: Göttinger Nachr. I905, Heft I; Löwenstein: $Z$. physik. Chem. 54, 7 I5.

${ }^{6}$ Haber and van Oordt: $Z$. anorg. Chem. 44, 34I ( I905). 